\title{
ЕКОЛОГІЧНА ОСВІТА МОРЯКІВ ЯК УМОВА ЗАБЕЗПЕЧЕННЯ СТАЛОГО РОЗВИТКУ ЛЮДСТВА
}

Байрамова О. В.

\section{ВСТУП}

Все більшу увагу в умовах загострення екологічних проблем в усьому світі приділяють екологічній освіті та вихованню людей. Розробляються концепції розвитку екологічної освіти та реформування систем освіти 3 урахуванням екологічної компоненти. У найважливіших міжнародних документах останнього десятиріччя велика увага приділяється екологічній освіті, культурі й свідомості, інформованості людей про екологічну ситуацію у світі, їхній обізнаності 3 можливими шляхами вирішення різних екологічних проблем, 3 концептуальними підходами до збереження біосфери і цивілізації. Шлях до високої екологічної культури лежить через ефективну екологічну освіту. Екологічна освіта у XXI сторіччі $\epsilon$ пріоритетним напрямом у гармонізації відношень суспільства і природи, але стан екологічної освіти в Україні та за кордоном викликає занепокоєння.

Екологічне виховання й інформування населення, підготовка висококваліфікованих фахівців з високим рівнем екологічної культури $€$ одним із найважливіших і необхідних засобів здійснення переходу до гармонійного розвитку всіх країн світу. Екологічна проблематика в сучасному світі постає як вкрай важлива, що потребує концентрації науково-теоретичних і практичних зусиль для вирішення іiі нагальних проблем. Виконання введених у всьому світі вимог із захисту навколишнього середовища потребує суттєвих технічних змін, фінансових внесків як з боку приватного бізнесу, так і з боку держав. Але превентивний вплив на прийняття таких рішень неможливо здійснити без трансформації споживчого типу світогляду сучасної людини.

Впровадження екологічної освіти в інтересах сталого розвитку є одним із пріоритетних напрямів конструювання освітньої стратегії у світі. Досвід країн ЄС свідчить, що, базуючись на принципах екологічно-орієнтованої державної політики, активній позиції та високому рівні екологічної культури й відповідальності людини в природоохоронній діяльності, можна покращити стан навколишнього середовища. 
Незважаючи на велику кількість наукових робот із проблем екології, наукова та педагогічна спільнота відчуває гостру необхідність сучасного осмислення реального стану екологічної освіти, який, на жаль, без перебільшення можливо назвати недостатньо ефективним. Окремої уваги потребують питання розвитку екологічної освіти у морських закладах вищої освіти. Сьогодні у зв'язку з необхідністю реалізації екологічних принципів у галузі морської діяльності особливої актуальності набуває екологічна освіта майбутніх моряків, оскільки від сформованості екологічної компетентності фахівців морського флоту безпосередньо залежить збереження стану Світового океану, захист його від забруднення. Проблема екологічного виховання в морській освіті також фактично залишається відкритою та недостатньо дослідженою. Актуальним постає питання підвищення рівня екологічної свідомості, освіти на основі формування активної громадянської позиції молоді та модернізації освітнього простору на основі ідей сталого розвитку. Тому екологізація загалом усієї системи освіти i виховання $\epsilon$ надзвичайно актуальною темою сучасного розвитку суспільства. Метою нашого дослідження $€$ аналіз особливостей реалізації екологічної освіти в процесі підготовки висококваліфікованого фахівця морського флоту. Проаналізовано засоби екологічної освіти, яка $\epsilon$ одною 3 умов реалізації компентентнісного підходу в морській освіті як основного напряму іiі модернізації.

\section{1. Екологічна освіта як шлях до формування екологічної культури суспільства}

Для забезпечення сталого розвитку та раціонального використання природних ресурсів важливою умовою $\epsilon$ підвищення рівня інформованості всіх груп населення, яке досягається за допомогою екологічної освіти і виховання, що сприяє формуванню екологічної культури суспільства. Засвоєння екологічних та етичних норм, цінностей, професійних навичок досягається за допомогою цілеспрямованого екологічного виховання, екологічної освіченості особистості, емоційно-морального і відповідального ставлення до природи.

Сьогодні все більш розповсюдженою є думка про те, що більшість соціальних, економічних, політичних, екологічних та інших проблем зумовлені розбіжністю домінуючого світогляду людей 3 реальним буттям суспільства. Природним у такому контексті $\epsilon$ надія на вдосконалення системи освіти та виховання, які є важливою умовою вирішення усього комплексу доленосних для суспільства проблем. Екологічні проблеми глобального масштабу XXI ст. являють собою нову соціально-екологічну картину світобудови. 
Продуктивність вирішення питань екологізації залежить не тільки від інноваційної техніки, технологій, але й від загальної екологічної освіти, передусім сучасної молоді. Через це екологічна освіта розглядається у сучасному світі як соціально-педагогічна проблема, яку необхідно вирішити за допомогою навчання на основі сучасних знань про екологію, i насамперед студентської молоді як майбутніх конкурентоздатних фахівців на вітчизняному та світовому ринку праці. Екологічна ситуація у світі розглядається як наслідок низького рівня екологічної культури людей, переважання цінностей техногенної цивілізації, зниження рівня екологічних вимог у суспільній свідомості. Таке важливе завдання можливо здійснити, тільки якщо виховувати фахівців з високим рівнем екологічної культури та освіченості.

В Україні до недавнього осмислення теоретичних засад екологічної освіти проводилось майже виключно з марксистської точки зору, але не ігнорувалися праці К.Е. Ціолковського, В.I. Вернадського, А.Л. Чижевського та ін. Проблема ролі й місця екологічної освіченості цікавить багатьох науковців. Питання формування загальної екологічної культури осмислювалися в публікаціях В. Андрущенка, Н. Авраменко, Ю. Алферова, Г. Бачинського, В. Вернадського, Л. Губерського, М. Кисельова, Б. Коммонера, Ю. Одума, А. Печчеї та інших відомих вітчизняних та іноземних учених. Загальні проблеми проектування екологічної освіти в технічному ЗВО представлені в роботах О. Плахотнік, В. Прозорової, Н. Пустовіт. Першочергові завдання вдосконалення екологічної освіти і виховання в Україні $\epsilon$ основою науково-практичних досліджень Г. Білявського. Проблему формування екологічного світогляду в студентської молоді вивчають сучасні українські науковці: Н. Негруца, Н. Немченко, С. Совгіра. Екологічна освіта розглядається вченими в контексті загальної освіти особистості, а її реалізація здійснюється в ході вивчення традиційних курсів екології, безпеки життєдіяльності. Освітні аспекти в структурі екобезпечного розвитку суспільства як конкретні соціокультурні, гуманістичні та освітні проекти представлені у філософських працях: Т. Андрущенко, А. Абрамової, Г. Берегової, А. Бойко, Н. Бугайової, М. Бургіна, В. Вашкевича, В. Воронкової, Е. Герасимової, О. Джури, Д. Дзвінчука, О. Кивлюк, Н. Кисельова, С. Клепка, Н. Кочубей, С. Крилової, С. Куцепал, Н. Лавриченка, М. Левшина, В. Покася, I. Предборської, Т. Розової, О. Удода, В. Сластьоніна, І. Суботіної, А. Ярошенко та інших. Але сучасний стан екологічної освіти, незважаючи на велику кількість наукових робот із проблем екології, без перебільшення можливо назвати недостатньо ефективним.

Суспільна екологічна свідомість натепер знаходиться на стадії формування і включає сукупність ідей, теорій, поглядів, мотивацій, що відбивають екологічну сторону суспільного буття. Більшість учених зрозуміли, що запобігти екологічній катастрофі можна лише за умови 
формування певної «критичної маси» людей, вихованих на ідеях екологічної філософії життя. 3 точки зору дослідників А.А. Ниязової, Е.Ф. Садикової ${ }^{1}$, сьогодні можливо виокремити такі аспекти нової екологічної парадигми:

- науковий аспект, який забезпечує розвиток пізнавального відношення до навколишнього середовища. Він включає в себе природничо-наукові, соціологічні та технологічні закономірності, теорії, поняття, що характеризують природу, людину, суспільство та виробництво у взаємодії;

- ціннісний аспект, який формує моральне та відповідальне ставлення до навколишнього середовища. Сучасна молодь формує естетичне сприйняття оточуючого світу, а також активну екологічно спрямовану життєву позицію;

- нормативний аспект, який орієнтує молодь на придбання системи знань правового характеру в галузі екології;

- діяльнісний аспект, який визначає засоби діяльності людини, спрямовані на формування теоретичних, практичних екологічних навичок.

Нова екологічна парадигма є багатоступеневою, формальною та неформальною та орієнтує сучасну молодь на здобуття інноваційних екологічних знань, формування дослідницьких навичок у сфері охорони навколишнього середовища, а також екологічної культури. Більш того, саме активні процеси екологізації всіх сфер життєдіяльності людини представляються сучасній молоді як абсолютна цінність на шляху до подолання глобальних, національних, регіональних і локальних екологічних загроз і зміцнення світової безпеки.

Екологічна освіта розглядається вченими в контексті загальної освіти особистості, а їі реалізація здійснюється в ході вивчення традиційних курсів екології, безпеки життєдіяльності. Важливість наукового осмислення методів, умов, засобів екологічної освіти майбутнього фахівця зумовлена також соціокультурними потребами в розвитку здібностей студентів, у формуванні екологічного світогляду.

Одна 3 перших статей про екологічне навчання 3'явилась у «Тhe Journal of Environmental Education» в 1969 році, автором якого $є$ William B. Stapp, який став першим директором з екологічної освіти при ЮНЕСКО, а потім - у Global Rivers International Network. У 1970 році була створена Національна Асоціація Екологічного навчання задля просування екологічних навчальних програм. У 1972 році на Конференції $\mathrm{OOH}$ із проблем навколишнього середовища в Стокгольмі

1 Ниязова А.А., Садыкова Э.Ф. Основные научные подходы, используемые в решении экологических проблем. Современные проблемы науки и образования. 2013. № 1. C. 17-23. 
було зроблено заяву про те, що екологічна освіта має бути інструментом задля вирішення глобальних екологічних проблем. У тому ж році ГА ООН створила Програму ООН з навколишнього середовища ЮНЕП. ЮНЕСКО та ЮНЕП створили три головні декларації, які становлять напрями екологічної освіти: Стокгольмську декларацію (1972), Белградську хартію (1975), Тбіліську декларацію (1977). ЮНЕСКО стверджує, що екологічна освіта є життєво важливою для підвищення суспільної екологічної свідомості. Це положення підкреслюється і в останніх міжнародних документах (міжнародний звіт «Ріо+5», «Керівництво 3 підготовки національних доповідей про виконання країнами «Порядку денного на XXI сторіччя» тощо). Також про необхідність формування екологічного світогляду студентів йдеться також в екологічній програмі ЮНЕСКО «Людина та біосфера» (MAB - Man and Biosphere).

Підготовка громадян 3 високим рівнем екологічних знань, екологічної свідомості та культури на основі критеріїв гармонійного співіснування 3 природою має стати одним із головних важелів у вирішенні як екологічних, так і соціально-економічних проблем сучасної України. Визнання провідної ролі освіти серед заходів, спрямованих на вирішення екологічних проблем, знайшло відображення в нормативних документах також у нашій країні. Необхідність формування екологічної освіти як складника гармонійно розвиненої особистості відображено в Державній національній програмі «Освіта. Україна XXI століття», в Концепції національного виховання, Державному стандарті освіти в Україні. Відповідно до «Концепції екологічної освіти України» одним з основних стратегічних напрямів розвитку екологічної освіти $є$ формування покоління з високим рівнем екологічної культури та екологічного світогляду, а одним із провідних завдань освіти та виховання $\epsilon$ формування всебічно розвиненої особистості, невід'ємною складовою частиною якої $є$ екологічний світогляд ${ }^{2}$. Варто зазначити, що ще в січні 2003 року у Верховній Раді України відбулися слухання про стан дотримання природоохоронного законодавства в Україні. Дійшли висновку, що через низький рівень дотримання вимог природоохоронного законодавства стан природного середовища в Україні майже критичний, тому що відсутня стратегічна екологічна політика. «Національна стратегія розвитку освіти в Україні на період до 2021 року» визначає, що стрижневим завданням освіти у XXI столітті $\epsilon$ розвиток мислення, орієнтованого на майбутнє. Однак реально

2 Шумілова А.В. Формування екологічної свідомості еколого-освітніми заходами. Вісник ХНУ імені В.Н. Каразіна. Серія «Екологія». 2015. № 13. URL: http://journals.uran.ua/visnukkhnu_ecology/article/viewFile/58410/54308 (дата звернення: 14.11.2019). 
екологічна освіта i виховання не стали обов'язковою частиною навчального процесу на всіх його рівнях.

Концепція екологічної освіти України як елемент концепції гармонійного розвитку держави набуває сьогодні ваги актуального і важливого державного документа. Державна політика в галузі екологічної освіти повинна базуватися на таких принципах: розповсюдження системи екологічної освіти і виховання на всі верстви населення 3 урахуванням індивідуальних інтересів, стимулів та особливостей соціальних, територіальних груп та професійних категорій; комплексності екологічної освіти і виховання; неперервності процесу екологічного навчання в системі освіти, в тому числі підвищення кваліфікації та перепідготовки ${ }^{3}$. Перелічені особливості вимагають розробок специфічного навчально-методичного забезпечення екологічної освіти. Екологічна освіта, 3 одного боку, повинна бути самостійним елементом загальної системи освіти, а 3 іншого боку - виконувати інтегративну роль у всій системі освіти. Створені програми повинні бути інтерактивними, цілісними, комплексними, адаптованими під компетентнісно-орієнтоване навчання. Останнім часом у педагогіці почались активні обговорення питань екологічної освіти для сталого розвитку. Всесвітній план дій на XXI ст. являє собою модель сталого розвитку, тобто таку модель соціально-економічного розвитку суспільства, яка життєві потреби людей сьогодні задовольняє з урахуванням прав майбутніх поколінь на життя у здоровому та невиснаженому середовищі. Сьогодні наявна консолідація всіх держав світу задля вирішення проблеми сталого, збалансованого економічного, соціального, екологічного розвитку суспільства, в якому головну роль має освіта.

У наукових дослідженнях існує велика кількість тлумачень дефініції «екологічна освіта», які часто мають суттєві розбіжності. На нашу думку, надзвичайно слушним є визначення Л.Б. Лук'янової: «...екологічна освіта - це не частина освіти, а новий сенс і мета сучасного освітнього процесу - унікального засобу збереження й розвитку людини і продовження людської цивілізації, це процес, який перебуває у постійному розвитку і $є$ результатом переорієнтації та узгодження різних дисциплін» ${ }^{4}$. Завдання й принципові положення екологічної освіти націлені на різнобічну підготовку студентської молоді, яка зможе вирішувати екологічні проблеми на основі наукових знань процесів розвитку біосфери, здорового глузду та набутого досвіду.

\footnotetext{
${ }^{3}$ Радіонова Г.О., Кретова А.В. Напрямки виховання екологічної культури в молоді шляхом підвищення рівня екологічної освіти. URL: http//www.rusnauka.com/ 1_NIO_2008/Ecologia/25453.doc.htm (дата звернення: 20.12.2019).

4 Лук'янова Л.Б. Теорія і практика екологічної освіти у професійно-технічних навчальних закладах : дис. ... докт. пед. наук : 13.00.04. Київ, 2006. 465 с.
} 
Базою для здійснення заходів з вирішення цієї важливої і складної державної проблеми має стати «Концепція екологічної освіти України». Екологічна освіта повинна включати в себе неформальні компоненти, які передбачають використовування в плануванні та реалізації освіти різноманітних форм екологічного виховання (наприклад, організація тимчасових фотовиставок екологічного змісту, екологічних фестивалів, конкурсів, організація лекцій сумісно з представниками громадських екологічних організацій, фахівців-екологів найвищої кваліфікації, організація публічних екологічних дискусій на злободенні екологічні проблеми). Доцільність застосування неформальної частини екологічної освіти необхідно передбачати в період складання навчальних планів і програм, організації навчального процесу в цілому. Важливо реалізувати саме цілісний підхід до екологічної освіти, а також забезпечити дотримання психолого-педагогічних принципів екологічної освіти та виховання. Безсумнівно, що в процесі навчання треба забезпечити не тільки набуття відповідних знань 3 екології та вміння обгрунтовувати свої світоглядні позиції у сфері екології, а й активне і повсякчасне використання їх у професійній діяльності, повсякденному житті та навіть у побуті. У зв'язку 3 цим процес екологічної освіти повинен розумітися не тільки як процес засвоєння певної системи екологічних знань, умінь і компетенцій, що становлять інструментальну основу навчально-пізнавальної діяльності молоді, але i як процес розвитку ціннісних орієнтацій особистості, прийняття екологічних цінностей. Мета екологічної освіти досягається в єдності таких завдань:

- освітніх - формування системи знань про екологічні проблеми сучасності та шляхи їх вирішення;

- виховних - формування мотивів, потреб і звичок екологічної діяльності;

- розвиваючих - розвиток системи інтелектуальних і практичних умінь із вивчення, оцінки стану i поліпшення навколишнього середовища.

Екологічна освіта розглядається як сукупність таких компонентів: екологічні знання, екологічне мислення, екологічний світогляд, екологічна етика, екологічна культура. Кожному компоненту відповідає певний ступень екологічної освіти: від елементарних знань до глибокого усвідомлення. Розвиток вищої екологічної освіти повинен базуватися на комплексному збалансованому поєднанні природничого, технологічного, економічного, юридичного i соціокультурного підходів. Першочерговим завданням розвитку вищої екологічної освіти $€$ розроблення програм навчальних курсів з екології згідно з вимогами часу, міжнародними принципами, можливостями 3ВО, потребами регіонів та відповідними стандартами. 


\section{2. Особливості екологічної освіти курсантів морських ЗВО}

Морський торговельний флот є однією з найбільш розвинених галузей світової економіки. Специфіка роботи на суднах у морі потребує постійного їх оновлення новим сучасним технічним обладнанням, поліпшення якості фахової підготовки морських фахівців на основі навчання моряків компетентно здійснювати професійну діяльність, дотримуючись вимог Міжнародної Морської Організації (IMO), Конвенції ПДНВ 78/95 3 Манільськими поправками 2010 року. Глибоким опануванням екологічних знань, формуванням екологічного мислення, свідомості та культури мають бути охоплені всі студенти морських навчальних закладів. Екологічно безпечний розвиток повинен бути базисною ідеєю, методологічною основою екологічної освіти згідно 3 міжнародними вимогами. $\mathrm{У}$ морській галузі розвиток техніки з урахуванням нових екологічних вимог забезпечується International Maritime Organization (IMO) - агентством OOH, що координує міжнародне судноплавство і захист морського середовища. Безпосередньо з питань захисту морського середовища працює спеціалізований комітет IMO Marine Environment Protection Commitee (MEPC).

Сьогодні у зв'язку з необхідністю реалізації екологічних принципів у галузі морської діяльності особливої актуальності набуває екологічна освіта майбутніх моряків. Проблема екологічного виховання в морській галузі фактично залишається відкритою та недостатньо дослідженою.

Важливість наукового осмислення методів, умов, засобів процесу екологізації освіти майбутнього фахівця морської галузі зумовлена необхідністю здійснювати професійну діяльність з урахуванням вимог міжнародно-правових актів, наприклад, Міжнародної конвенції про запобігання забрудненню із суден (МАРПОЛ 73/78), Конвенції про цивільну відповідальність за збитки від забруднення нафтою, регіональних міжнародних угод про запобігання забрудненню окремих морських басейнів Балтійського моря, Середземного моря, Перської, а також деяких інших угод. Відповідно, стратегія розвитку, перш за все системи морської освіти, повинна формуватися навколо впровадження ідеї екологізації освітнього простору, що сприяє прискоренню процесу інтеграції національної системи освіти в європейський і світовий освітній простір.

Екологічна освіта передбачає формування системи поглядів, ідей, практичних дій адміністрації, викладачів, курсантів, які здатні забезпечити екобуття молоді, реалізувати ії науковий, професійний, особистісний потенціал, що надає можливість ефективно вирішувати екологічні завдання під час навчання, практики та в майбутній професійній діяльності з урахуванням відповідальності за природу, своє життя та життя інших людей.

На жаль, традиційна «реальна» модель освіти в морських закладах вищої освіти (3ВО) орієнтована більше тільки на передачу спеціальних 
знань, по формату реалізації має авторитарний характер. Проблемними питаннями ефективного запровадження екологічної освіти у морському ЗВО $є$ обмежена кількість годин, виділених на викладання природничих дисциплін, обмежена можливість введення в навчальновиховний процес систематично діючих додаткових курсів, тренінгів, недостатня мотивація курсантів перших курсів для отримання екологічних знань.

Сьогодні існує низка суперечностей між інноваційною політикою держави у сфері вищої освіти та недостатнім рівнем теоретичного, практичного, методологічного рівня розробленості ефективної реалізації екологічної освіти. Крім того, необхідно забезпечити ефективний механізм підвищення рівня мотивації, активної громадянської позиції в екологічно безпечній діяльності, екологічної свідомості та культури всіх без винятку викладачів ЗВО. Аналіз сучасного стану екологічної освіти в морських закладах освіти свідчить про недостатню ефективність, формалізм іiі реалізації.

Формування екологічної культури студентів морських ЗВО передбачає не тільки озброєння ї знанням змісту міжнародних конвенцій 3 охорони навколишнього середовища та запобігання забруднення моря, але й створення особливого внутрішнього світу, екологічно відповідального світогляду та поведінки. Екологізація морської освіти розглядається як важлива сучасна тенденція в освітній системі. Вона передбачає реалізацію принципів міждисциплінарності, інтегративності, системності, науковості, послідовності. У морських ЗВО необхідно створити таку екологічно-орієнтовану освітню платформу, яка буде зорієнтована на взаємозв'язок професійної підготовки курсантів 3 конкретними завданнями науково-технічного прогресу.

Однією 3 вимог реалізації екологічно-орієнтованих освітніх стратегій $є$ стимулювання проведення міждисциплінарних науководослідницьких пошуків еконапряму, проведення заходів із презентації екологічних проектів, участь у роботі міжнародних екологічних організацій (Global Nest, World Society for the Protection of Animals, World Wide Fund for Nature, European Environment Agency). Дієвим механізмом формування екологічного імперативу в курсантів $\epsilon$ створення в навчальному закладі екологічної організації студентів та випускників. Студентський екоцентр надає можливість придбати початкові навички природоохоронної діяльності, а для молоді з високим рівнем екологічної свідомості - самореалізуватися у вітчизняних та міжнародних молодіжних проектах, грантових програмах. Популяризації принципів сталого розвитку серед курсантів сприяе проведення різноформатних екологічних заходів фотовиставок, ре-арт студій (майстер-класів), тренінгів з особистого розвитку тощо. Створення екологічно-орієнтованого освітнього 
простору в закладі вищої освіти $€$ важливою умовою i засобом формування особистості 3 високим рівнем екологічної свідомості та мислення.

Одним із суб'єктивних факторів, які гальмують створення системи неперервної екологічної освіти, $\epsilon$ те, що в практиці не завжди використовуються наявні для цього можливості. Хибною є позиція, відповідно до якої основне навантаження з екологічної освіти повинно відбуватися тільки в процесі викладання окремих дисциплін. Провідним $є$ положення про те, що в досягненні головної мети екологічної освіти $\epsilon$ інтеграція всіх навчальних предметів, бо в кожному з них закладено свій екологічний потенціал ${ }^{5}$.

До навчального процесу в системі вищої освіти впроваджується два підходи до розгортання змісту екологічної освіти: перший мультидисциплінарний (екологізація існуючих навчальних предметів відповідно до специфіки їхнього змісту). Другий - внутрішньодисциплінарний (введення до навчального плану спеціального предмета екологічного змісту). За першого підходу виділяється екологічний компонент у більшості навчальних дисциплін. Наприклад, у навчальних дисциплінах «Технологія використання робочих речовин», «Автоматизація суднових енергетичних установок» та «Суднові допоміжні механізми, устрої та системи» (СДМ) потрібно додати інформацію з екологічних питань по загальних проблемах для всіх суден водного транспорту. Такий формат реалізації змісту освіти дозволяє знання з наукової, соціальної, економічної, технічної сфери синтезувати на екологічне знання. Це дозволить курсантам зрозуміти значущість екологічної освіти не тільки для формування екологічної культури, а й для професійної підготовки. Наприклад, знання нормативних документів, питань устрою та експлуатації судна дає змогу на практичних заняттях 3 навчальної дисципліни «Суднові дизельні установки» проводити оцінку екологічних показників роботи дизеля, а на заняттях «Суднові котельні установки» вивчають питання підвищення якості повітря та відведення газів (Додаток VI до Конвенції МАРПОЛ 73/78). Доцільно в межах програмного матеріалу зазначених дисциплін звернути увагу на заходи щодо покращення екологічних показників відпрацьованих газів, які виділяються в атмосферу під час експлуатації суден.

За внутрішньо-дисциплінарного підходу вводиться спеціальний предмет екологічного змісту. Відповідно до вимог освітніх програм у морських навчальних закладах введено, наприклад, дисципліну «Екологія та охорона навколишнього середовища», яка має сприяти

5 Курняк Л.М.Екологічне виховання студентів ВНЗ. Збірник наукових праць Хмельницького інституту соиіальних технологій Університету «Украӥна». 2012. № 5. C. 109-114. 
екологічному вихованню курсантів. Таким чином, екологічні знання протягом ряду занять із більшості навчальних дисциплін перейдуть у переконання необхідності жити в гармонії з природою. Знання, переведені в переконання, поступово сформують екологічну свідомість та екологічну культуру.

Екологічна культура курсантів морських 3ВО формується в процесі екологічної освіти в контексті різноманітних напрямів діяльності формування активної позиції молоді, екологізації фахових навчальних дисциплін, мотивування студентів до науково-дослідницької діяльності, яка інтегрує зміст фахової та екологічної освіти, участі в екологічних проектах, міжнародному стажуванні, волонтерських екозаходах, дискусійних форумах.

Головними складниками екологічної освіти в морському 3ВО мають бути не тільки формальна, а й неформальна частини, форми й методи яких різні, а мета одна: різнобічна підготовка студентів, здатних аналізувати та вирішувати екологічні та соціально-економічні проблеми на основі наукових знань, загальнолюдських цінностей та досвіду.

Зміст навчання повинен сприяти подальшому розширенню і поглибленню екологічної культури особистості в процесі професійної підготовки фахівця, а складники змісту екологічної освіти у професійній освіті повинні мати інваріантний та варіативний компоненти. Перший має гуманітарно-світоглядну спрямованість і висвітлює стан сучасної науково-природничої картини світу з точки зору екології, головні етапи становлення екології, основні екологічні поняття й визначення, рівні організації і функціонування екологічних систем, значення екологічних систем, значення екологічної безпеки як складової частини загальної безпеки України, екологічне нормування впливу на природне середовище, міжнародну співпрацю у справі збереження та відновлення довкілля, екологічну культуру і мораль нової цивілізації. Інваріативний компонент має забезпечити обов'язковий мінімум змісту окремого курсу «Екологія та охорона навколишнього середовища», який, на жаль, має дуже обмежену кількість годин на його вивчення. Другий, варіативний компонент повинен висвітлювати аспекти екології 3 професійним спрямуванням, тобто його зміст залежить від освітніх потреб та обставин. Така побудова змісту екологічної педагогіки й освіти у вищій школі враховує екологічні імперативи.

У сучасному морському ЗВО важливим $є$ підвищення екологічної культури викладачів, що передбачає розвиток навичок 3 екологізації процесу викладання. Важливим кваліфікаційним критерієм викладача $€$ високий рівень екологічної компетенції. Сучасний викладач повинен мати екологічне мислення, досвід екологічно-орієнтованих дій, розуміти свої правові та моральні обов'язки в природоохоронній галузі. 
Кожний викладач повинен розвивати погляди, цінності, які мотивують його формувати особисті навички сталого розвитку - брати на себе відповідальність за потребу майбутніх поколінь, розвивати професійне мислення та внутрішню мотивацію. Екологічна компетенція відноситься до кожного викладача незалежно від того, яку навчальну дисципліну він викладає. Від рівня сформованості екологічної компетенції педагога залежатиме рівень реалізації завдань екологічної освіти в сучасному морському ЗВО. Фахівець вищої школи повинен переформувати навчальний процес від передавання знань до розгляду проблеми і стимулювання діяльності з розроблення можливих шляхів іiі вирішення. Ефективність екологічної освіти визначається також особистою готовністю педагога до вирішення професійних задач та проблем, які виникають у реальному навчальному процесі. Екологічна компетентність викладача повинна базуватися на синтезі професійних, екологічних, педагогічних та методичних знань.

У процесі вивчення курсу «Екологія та охорона навколишнього середовища» курсантам доцільно працювати 3 додатковою науковою та науково-популярною літературою 3 проблем екології, практичні заняття можливо проводити у вигляді дискусій, після моделювання виробничих та практичних ситуації тощо. Традиційному навчальновиховному процесу морського ЗВО властиве переважання вербальних методів спілкування, недооцінка значення комунікативної взаємодії, відсутність цікавих форм організації навчальної діяльності тощо. Тому педагогічна практика потребує впровадження також ігрових методів, які покликані активізувати діяльність студентів. До ігрових методів навчання відносяться: ділові ігри, дидактичні ігри, ігри-змагання. Модифікаціями ділової гри можна вважати бліц-гру, гру-вправу, рольову, операційну, імітаційну ігри тощо. Необхідно активізувати участь студентів у різноманітній дослідно-експериментальній, природоохоронній діяльності, організовувати екологічні клуби, гуртки, екологічні табори, формувати екологічні агітбригади. Навчальний процес у сучасному морському ЗВО має всі можливості з формування організаторських здібностей курсантів, наприклад, в організації та проведенні екологічних заходів, еколого-просвітницької діяльності з учнями загальноосвітніх навчальних закладів (у формі презентацій, тренінгів, ділових ігор тощо).

Використання інтерактивних методів у процесі навчання професійних і спеціальних дисциплін із включенням екологічних знань дозволяє вирішити задачу формування екологічного навчального середовища. Це дозволяє вирішити багато дидактичних та виховних задач: засвоєння екологічних знань, самостійний пошук проблеми та шляхів ऑiі вирішення, пробудження зацікавленості студентів до екологічних знань, формування екологічної освіченості, активної життєвої позиції, екологічної культури, вихід студентів на рівень 
свідомого відношення та особистої відповідальності за навколишне середовище ${ }^{6}$. Тому інтерактивне навчання орієнтує на активне засвоєння учбового матеріалу, більш сутнісне його розуміння, розвиток навичок рішення комплексних соціально-екологічних завдань. Навчання через співпрацю також сприяє розвитку здібності сприймати іншу думку i вирішувати конфлікти, що $є$ дуже важливим для професійної діяльності моряків.

Екологічна освіта сьогодні повинна переорієнтувати кінцеві цілі морської освіти та трансформувати іiі зміст. Таким чином, єдина понятійна основа екологічних знань дозволяє концептуально поєднати розрізнені екологічні поняття і знання різних дисциплін, пов'язати єдиним підходом екологічні питання, усвідомити системні зв'язки, сформувати цілісне уявлення про навколишній світ як систему «природа - людина - суспільство». Результатом постає формування сучасного екологічного системно-вірогідного мислення, системи екологічних знань, екологічного імперативу відповідальної особистості ${ }^{7}$. Розвиток екологічного мислення залежить від вивчення багатьох дисциплін, викладання яких засновано на принципах системності, взаємозалежності, інтеграції та єдності екологічних знань.

Забезпечення процесів самореалізації та особистого росту студентів - головні умови формування екологічного світогляду. Система професійної морської освіти повинна бути побудована таким чином, щоб у ракурсі певних етичних установок допомогти студентові сформувати навички поведінки і навчити передбачати наслідки своєї професійної діяльності для людини, Світового океану та біосфери. Ідея контекстного підходу у викладанні дисциплін гуманітарного циклу має важливе значення. Реалізація цієї форми складання навчального змісту уможливлює, по-перше, встановлення міждисциплінарних зв'язків, що сприяють формуванню цілісного уявлення про навколишній світ, а подруге, підтверджується значення екологічної культури в структурі загальної культури студента та як компонента професійної культури. Також контекстний підхід реалізує можливість насичення спеціальних дисциплін екологічним змістом без порушення логіки викладу дисципліни «Екологія та охорона навколишнього середовища». Суттєве поліпшення професійної підготовки майбутнього фахівця морської галузі можливе за умови розроблення сучасних теоретичних і методичних засад навчання на основі формування екологічної компетенції курсантів.

6 Даниленкова В.А. Интерактивные методы обучения в экологической образовательной среде морского технического вуза. Молодой ученый. 2015. № 2. С. $510-513$.

Андрущенко В.П. Екологічна політика і освіта: проблеми становлення. Роздуми про освіту : статті, нариси, інтерв'ю. Київ, 2004. С. 253-258. 
На жаль, традиційна «реальна» модель освіти в морських $3 \mathrm{BO}$ орієнтована більше тільки на передачу спеціальних знань, по формату реалізації має авторитарний характер. Проблемними питаннями ефективного запровадження екологічної освіти у морському 3ВО $€$ обмежена кількість годин, виділених на викладання природничих дисциплін, обмежена можливість введення в навчально-виховний процес систематично діючих додаткових курсів, тренінгів, недостатня мотивація курсантів перших курсів для отримання екологічних знань.

Сьогодні існує низка суперечностей між інноваційною політикою держави у сфері вищої освіти та недостатнім рівнем теоретичного, практичного, методологічного рівня розробленості ефективної реалізації екологічної освіти. Крім того, необхідно забезпечити ефективний механізм підвищення рівня мотивації, активної громадянської позиції в екологічно безпечній діяльності, екологічної свідомості та культури всіх без винятку викладачів ЗВО. Аналіз сучасного стану екологічної освіти в морських закладах освіти свідчить про недостатню ефективність, формалізм іiі реалізації.

\section{ВИСНОВКИ}

Для формування екологічної освіти студентів морських навчальних закладів необхідно забезпечити дієвий механізм з введення екологічних знань в учбовий процес, скоординувати зусилля різних курсів та кафедр, обмін інформацією, досвідом, методологічним і методичним забезпеченням, організацію виховного процесу. Сучасна екологічна освіта потребує поліпшити зміст навчальних програм, переглянути зміст і структуру освітньо-професійних програм майбутніх фахівців рівнів вищої освіти «Бакалавр», «Магістр», включивши до їхньої структури екологічний компонент, удосконалити підручники, збільшити випуск літератури екологічного профілю, навчальні посібники, методичні розробки, що відображають теоретичні й практичні основи екологічної освіченості й вихованості. Одним із найважливіших факторів підвищення ефективності екологічної освіти є дослідницький характер навчання, тому в силабусі, НМК треба передбачити якісну та ефективну організацію самостійної навчальнодослідницької роботи студентів. Поєднання теоретичних знань та практичних навичок по їх використанню можливе за умови активного впровадження нових форм та методів навчання, різних видів моделювання екологічних процесів чи ситуацій, проведення екскурсій на екологічні об'єкти. Формування екологічної компетентності студентів морських ЗВО - складний системний процес, який передбачає набуття знань й умінь та їх трансформацію в компетенції, а також світоглядні, морально-ціннісні та інші аспекти розвитку особистості. На нашу думку, формуванню екологічної компетентності майбутнього моряка буде сприяти: екологізація змісту всіх дисциплін 
природничо-наукової, професійної та практичної підготовки, міждисциплінарні зв'язки у процесі професійної підготовки. Питання міждисциплінарних зв'язків включені в навчальний процес під час формування екологічної компетентності. Це дає можливість випускнику застосовувати у професійній діяльності отриманні знання, які будуть направлені на збереження навколишнього середовища, оскільки це відповідає потребам сьогодення. У процесі викладання «Основ екології та охорони навколишнього середовища» у морському ЗВО викладач повинен брати до уваги специфіку предмета, дотримуватися стандарту, але може й поширювати одні розділи програми та скорочувати інші, використовуючи різноманітні методики викладання. Доцільним буде налагодити між морськими навчальними закладами України, освітніми закладами Свропи і США стійкі зв'язки та обмін досвідом, методологічними доробками щодо екологічної освіти й виховання, створити мережу інформаційних, методичних, тренінгових центрів, сумісних нових проектів, проведення науковопрактичних конференцій із запрошенням до участі студентів.

Екологічне навчальне середовище - це системний комплекс дій, націлений на формування екологічної свідомості, навіть світогляду. Сучасна екологічна освіта повинна бути націлена на майбутнє, на формування екологічної культури та грамотності, на створення умов для розвитку відповідальної особистості, яка має впевненість, що наслідки діяльності людини залежать від неї самої, від знань та вмінь передбачити ці наслідки. Сучасні глобальні, національні та регіональні екологічні виклики потребують негайного поновлення цілей та задач екологічної освіти i, як наслідок, iї очікуваних результатів. Перспективними напрямами подальших досліджень удосконалення, навіть модернізації екологічної освіти майбутніх моряків $є$ масштабна дослідна та науково-методична робота 3 уточнення змісту та форм екологічної освіти, а також розроблення методичних питань формування екологічної компетентності студентів 3 урахуванням міжнародних стандартів морської підготовки. Таким чином, створення екологічного освітнього середовища дозволить поліпшити не тільки якість професійної підготовки курсантів, але й підвищити ефективність розвитку сучасного морського ЗВО, для якого збалансований, екологічно безпечний (гармонійний) розвиток повинен бути базисною, вихідною ідеєю, методологічною основою екологічної освіти згідно 3 міжнародними вимогами.

\section{АНОТАЦІЯ}

Все більшу увагу в умовах загострення екологічних проблем в усьому світі приділяють екологічній освіті й вихованню людей. Впровадження екологічної освіти в інтересах сталого розвитку є одним iз пріоритетних напрямів конструювання освітньої стратегії у світі. 
Дослідження присвячено проблемі екологічної освіти в морських закладах вищої освіти, яка розглядається як одна 3 основних умов підготовки компетентного, висококваліфікованого фахівця морського флоту. Сьогодні у зв'язку 3 необхідністю реалізації екологічних принципів у галузі морської діяльності особливої актуальності набуває екологічна освіта майбутніх моряків, оскільки від сформованості екологічної компетентності фахівців морського флоту безпосередньо залежить збереження стану Світового океану, захист його від забруднення. Проаналізовано умови, засоби реалізації екологічної освіти, яка $є$ однією з форматів реалізації компетентнісного підходу в морській освіті. Наголошується на необхідності впровадження системного, комплексного підходу до екологічної освіти, екологічного світогляду, який базується на забезпеченні процесів самореалізації, підвищенні мотивації, активності не тільки курсантів, але й викладачів сучасного морського ЗВО. Система професійної морської освіти повинна бути побудована таким чином, щоб у ракурсі екологічних імперативів допомогти курсанту сформувати навички поведінки і навчити передбачати наслідки своєї професійної діяльності для людини, Світового океану, біосфери.

Високий рівень сформованості екологічної культури, екологічної освіченості моряків є необхідною умовою здійснення превентивних екологічних заходів, що сприяють реалізації екологічних стандартів у морській галузі, безпеки судноплавства, запобіганню аваріям та техногенним катастрофам. Саме екологічна освіта сьогодні стає захисно-пристосувальним механізмом виживання людини і суспільства в масштабах планети, країни, регіону.

\section{ЛIТЕРАТУРА}

1. Ниязова А.А., Садыкова Э. Ф. Основные научные подходы, используемые в решении экологических проблем. Современные проблемы науки и образования.2013. № 1. С. 17-23.

2. Шумілова А.В. Формування екологічної свідомості екологоосвітніми заходами. Вісник ХНУ імені В.Н. Каразіна. Серія «Екологія». 2015. № 13. URL: http://journals.uran.ua/visnukkhnu_ecology/article/ viewFile/58410/54308 (дата звернення: 14.11.2019).

3. Радіонова Г.О., Кретова А.В. Напрямки виховання екологічної культури в молоді шляхом підвищення рівня екологічної освіти. URL: http//www.rusnauka.com/1_NIO_2008/Ecologia/25453.doc.htm (дата звернення: 20.12.2019).

4. Лук'янова Л.Б. Теорія і практика екологічної освіти у професійнотехнічних навчальних закладах : дис. ... докт. пед. наук : 13.00.04. Київ, 2006. $465 \mathrm{c}$. 
5. Курняк Л.М. Екологічне виховання студентів ВНЗ. Збірник наукових прачь Хмельнищького інституту соціальних технологій Університету «Україна». 2012. № 5. С. 109-114.

6. Даниленкова В.А. Интерактивные методы обучения в экологической образовательной среде морского технического вуза. Молодой ученый. 2015. № 2. С. 510-513.

7. Андрущенко В.П. Екологічна політика i освіта: проблеми становлення. Роздуми про освіту : статті, нариси, інтервюю. Київ, 2004. C. 253-258.

\section{Information about author:} Bairamova O. V., Candidate of Philosophical Sciences, Associate Professor at the Department of Natural-Mathematical and Engineering-Technological Disciplines of the Danube Faculty of Maritime and River Transport State University of Infrastructure and Technologies 7, Fanagoriyskaya str., Izmail, Odesa region, Ukraine 